1 Fauci AS, Haynes BF, Katz P. The spectrum of vasculitis, clinical, pathological, immunological and therapeutic considerations. Ann Intern Med 1978;89: 660-76.

2 Wolff M, Fauci AS, Horn RG, Dale DC. Wegener's granulomatosis. Ann Intern

3 Camilleri M, Pusey CD, Chadwick VS, Rees AJ. Gastrointestinal manifestations of systemic vasculitis. $Q \mathcal{F}$ Med 1983;206:141-9.

4 Pinching AJ, Lockwood CM, Passell BA, et al. Wegener's granulomatosis: observations on 18 patients with severe renal disease. $Q \Im$ Med 1983;208:435-60. granulomatosis. $\mathrm{Br} f$ Med $1985 ; 290: 676$.

Accepted 4'fuly 1985)

Department of Nephrology and Transplantation, Royal Hallamshire

Hospital, Sheffield S10 2JF

R A COWARD, BM, MRCP, senior registrar

C P GIBBONS, DPHIL, FRCS, clinical research fellow

C B BROWN, MB, FRCP, consultant physician

A T RAFTERY, MD, FRCS, consultant surgeon

Department of Histopathology, Royal Hallamshire Hospital

M A PARSONS, MB, MRCPATH, senior lecturer

J R SHORTLAND, MB, MRCPATH, senior lecturer

Correspondence to: Dr Coward, Department of Medicine, Royal Hallamshire Hospital.

\section{Effect of treatment on symptoms and quality of life in patients with ulcerative colitis: comparative trial of hydrocortisone acetate foam and prednisolone 21-phosphate enemas}

The disability associated with ulcerative colitis and proctitis is considerable and includes decreased working capacity, early rising, increased bowel frequency, fear of incontinence, urgency, and tiredness. ${ }^{1}$ Sexual relationships may be adversely affected. Treatment itself may impose further restrictions on patients with this disease. We have compared the effects of foam and liquid topical corticosteroid preparations on the symptoms and quality of life of patients with distal ulcerative colitis.

\section{Patients, methods, and results}

We studied 46 patients ( 18 men, 28 women) aged 20-64 years with symptomatic relapse of chronic ulcerative colitis. All had histological confirmation of the diagnosis and sigmoidoscopic evidence of current exacerbation. Daily bowel frequency and severity of symptoms were assessed, urgency and lassitude being measured on visual analogue scales. Similar scales were used to assess disturbance of the quality of life caused by the treatment and by the disease, and patients also maintained daily symptom score cards. Treatmen with prednisolone 21-phosphate enemas (Predsol; $20 \mathrm{mg}$ prednisolone 21-phosphate in a buffered solution of $100 \mathrm{ml}$ ) or hydrocortisone acetate foam (Colifoam; $130 \mathrm{mg}$ hydrocortisone acetate in $5 \mathrm{ml}$ foam) was allocated blindly using a prearranged code. It was applied morning and evening for the first two weeks, then nightly for the next fortnight if responses were satisfactory. If responses were unsatisfactory the alternative treatment was supplied. Sigmoidoscopy was repeated after four weeks or if treatment was changed. Data were analysed non-parametrically using the Mann-Whitney U test (two tailed).

Five patients were excluded from analysis. In the enema group two showed poor compliance and one took medication for one week only, and in the foam group one patient was given the wrong medication and another was symptom free at entry. The groups did not differ materially in sex or age distribution, duration of disease or of recent episode, extent of disease, or numbers receiving concomitant sulphasalazine.

Treatments were equally effective in reducing bowel frequency, urgency, incontinence, and lassitude, but tenesmus was more completely alleviated at two weeks in those receiving the prednisolone enemas $(p<0.025)$. Sigmoidoscopic abnormalities improved similarly in both groups. After two weeks of treatment four patients changed from the foam to the enema because of poor response; two had slight symptomatic improvement and two did not. The one patient who changed from liquid treatment to foam did not benefit. No serious adverse reactions were reported.

Considerable disturbance of general activities due to the exacerbation of ulcerative colitis was recorded before treatment started. This decreased during treatment in both groups and was significantly reduced from baseline after four weeks. In all seven variables assessed, however, foam was associated with less interference with general activities than enema treatment, differences being significant for four of the daily activities examined (table). In addition, based on both the physicians' assessments and the patients; diary cards, significant differences favouring the foam were found for the criterion "difficulty of retention" $(p<0.05)$.

\section{Comment}

Other studies have shown that both prednisolone sodium phosphate enemas and hydrocortisone acetate foam are effective, ${ }^{2-5}$ but these have not been directly compared either for clinical value or for patient preference. In this trial the therapeutic efficacy of the two preparations differed little. By contrast, there was a clear difference between treatments in the degree to which they disturbed the quality of life.

Mean (range) analogue scale scores for disturbance of quality of life by treatment. (Scale rated from 0 (no disturbance) to 100 (maximum disturbance possible))

\begin{tabular}{|c|c|c|c|}
\hline \multirow[b]{2}{*}{ Component assessed } & \multirow[b]{2}{*}{ Treatment } & \multicolumn{2}{|c|}{ Duration of treatment } \\
\hline & & 2 weeks & 4 weeks \\
\hline Work or social activities & $\left\{\begin{array}{l}\text { Prednisolone } \\
\text { Hydrocortisone }\end{array}\right.$ & $\begin{aligned} & 23(0-99) * \\
& 4(0-29)\end{aligned}$ & $\begin{array}{r}11(0-60) \\
6(0-30)\end{array}$ \\
\hline Routine indoor activities & $\left\{\begin{array}{l}\text { Prednisolone } \\
\text { Hydrocortisone }\end{array}\right.$ & $\begin{array}{r}15(0-80) \\
4(0-30)\end{array}$ & $\begin{array}{r}14(0-63) \\
3(0-10)\end{array}$ \\
\hline Routine outdoor activities & $\left\{\begin{array}{l}\text { Prednisolone } \\
\text { Hydrocortisone }\end{array}\right.$ & $\begin{array}{r}17(0-81) \\
7(0-40)\end{array}$ & $\begin{array}{r}15(0-70) \\
3(0-10)\end{array}$ \\
\hline Early rising & $\left\{\begin{array}{l}\text { Prednisolone } \\
\text { Hydrocortisone }\end{array}\right.$ & $\begin{array}{c}23(0-100) \\
4(0-33)\end{array}$ & $\begin{array}{l}8(0-70) \\
2(0-10)\end{array}$ \\
\hline Sexual relationships & $\left\{\begin{array}{l}\text { Prednisolone } \\
\text { Hydrocortisone }\end{array}\right.$ & $\begin{array}{c}18(0-60)^{* * *} \\
1(0-3)\end{array}$ & $\begin{array}{r}15(0-89) \\
2(0-10)\end{array}$ \\
\hline Occupational activities & $\left\{\begin{array}{l}\text { Prednisolone } \\
\text { Hydrocortisone }\end{array}\right.$ & $\begin{array}{rl}12(0-40)^{*} & 2(0-14)\end{array}$ & $\begin{array}{l}4(0-15) \\
3(0-20)\end{array}$ \\
\hline Hobbies and recreation & $\left\{\begin{array}{l}\text { Prednisolone } \\
\text { Hydrocortisone }\end{array}\right.$ & $\begin{array}{r}12(0-50) \\
3(0-20)\end{array}$ & $\begin{array}{r}13(0-71) \\
3(0-20)\end{array}$ \\
\hline
\end{tabular}

Mann-Whitney U test (two tailed): *p $<0.05 ;{ }^{* *} \mathrm{p}<0.01$

This was particularly evident at two weeks, when the treatments were used twice daily, and was not attributable to variations in initial severity of the disease. Patients also preferred the foam to the liquid enemas because it was easier to retain.

Modern medicine tends to concentrate on disease, with less consideration for the effect which the disease or its treatment may have on the enjoyment of life. Our results suggest that, in distal ulcerative colitis, treatments which are equally effective clinically may nevertheless differ appreciably in the ways in which they influence the social, family, and professional life of the sufferers.

1 Mallet SJ, Lennard-Jones JE, Bingley J, Gilan E. Living with disease: colitis. Lancet 1978;ii:619-21.

Gaucher P, Champigneulle B. Local treatment of proctocolitis. Comparison between a betamethasone phosphate enema and a rectal foam containing hydrocortisone acetate. Revue Française de Gastroenterologie 1983;193:35-9.

21-phosphate retention enemata in proctocolit of ulcerative colitis. Dis Colon Rectum 1973;16:149-51.

5 Ruddell WSJ, Dickinson RJ, Dixon MF, Axon AIR. Treatment of distal ulcerative colitis (proctosigmoiditis) in relapse: comparison of hydrocortisone enemas and rectal hydrocortisone foam. Gut 1980;21:885-9.

(Accepted 24 fune 1985)

Department of Therapeutics, University Hospital, Nottingham

$\mathrm{K} W$ SOMERVILLE, MB, FRACP, lecturer

M J S LANGMAN, MD, FRCP, professor

Department of Gastroenterology, West Middlesex University Hospital, London

S P KANE, MB, MRCP, consultant physician

Department of Gastroenterology, Western Infirmary, Glasgow

A J MACGILCHRIST, MB, MRCP, registrar

G WATKINSON, MD, FRCP, consultant physician

Department of Gastroenterology, University College Hospital, London

P SALMON, MB, FRCP, consultant physician

Correspondence to: $\mathrm{Dr} \mathrm{K} W$ Somerville, Department of Therapeutics, Floor C, South Block, University Hospital, Nottingham NG7 2UH. 